\title{
EMOCJONALIZM ARYSTOTELESA I ZNACZENIE POJECIA KATHARSIS
}

\begin{abstract}
Artykuł przestawia zasadniczy problem w interpretacji pojęcia katharsis, który wyraża pytanie: ,jaki sens funkcji celowościowej należy przypisać kategorii katharsis?”. Do którego elementu „sytuacji tragicznej”, tworzonej przez poetę, oratora, aktora i odbiorcę, odnosi się to pojęcie? W historii dominowało ujęcie eksponujące oczywisty element tej sytuacji, czyli odbiorcę. Jednak w dwudziestym wieku pojawiły się nowe propozycje, zgodnie z którymi kategoria katharsis była odnoszona bądź do aktora, bądź do samego tekstu tragedii. Interpretacje te są dobrze znane i nie o nie tu chodzi. Przedmiotem zainteresowania jest propozycja, nazwijmy ją pluralistyczną, w której pojęcie to obejmuje wszystkie elementy sytuacji tragicznej.
\end{abstract}

Filozofowie starożytnej Grecji wypracowali trzy najogólniejsze paradygmatyczne stanowiska dotyczące sztuki (dzieła sztuki), które z różną mocą obowiązywały w kulturze europejskiej. Każde z nich było odpowiedzią na pytanie o cel spełniany przez sztukę (dzieło sztuki). Uogólniającym ujęciem wszystkich trzech teorii jest propozycja Władysława Tatarkiewicza, którą można uznać za próbę definicyjnego ujednolicenia tych trzech kanonów. Propozycja ta jest dobrze znana, niemniej warto ją przytoczyć raz jeszcze: „świadomy wytwór człowieka jest dziełem sztuki zawsze i tylko wtedy, gdy odtwarza rzeczywistość bądź kształtuje formy, bądź wyraża przeżycie, a zarazem jest zdolny bądź zachwycać, bądź wzruszać, bądź wstrząsać"1. Wskazanym artystycznym czynnościom odtwarzania, kształtowania i wyrażania odpowiadają trzy dobrze dzisiaj znane stanowiska teorii sztuki: mimetyzm, formalizm i ekspresywizm. Dla samej starożytności za najbardziej charakterystyczne można uznać

${ }^{1}$ W. Tatarkiewicz Droga przez estetykę Warszawa 1972 s. 36. 
stanowisko pierwsze, reprezentowane $\mathrm{z}$ jednej strony przez realizm Platona, $\mathrm{z}$ drugiej natomiast przez naturalizm Demokryta. Przedmiotem dalszych uwag jest jednak podejście ostatnie, wyrażone przez emocjonalizm Arystotelesa.

Szczególna sytuacja Poetyki Arystotelesa, będąca wynikiem historycznych losów dzieła, sprawiła, że pojawiło się wiele różnych interpretacji. Cechą wspólną tych propozycji jest wszakże to, że podkreślają one indywidualny charakter przeżycia, będącego wynikiem oddziaływania dzieła sztuki, a więc fakt, że przeżycie to jest ograniczone do jednego elementu, $i$ to zasadniczo do odbiorcy ${ }^{2}$. Podejście to, wsparte autorytetem tradycji, stało się naturalne i niekwestionowane. To może thumaczyć fakt, że propozycja odmiennego, opozycyjnego ujęcia katharsis nie zyskała należytej uwagi i pogłębionej dyskusji.

\section{1. \\ Katharsis indywidualne}

Przez kilka ostatnich wieków antyk był postrzegany w swym wyidealizowanym obrazie. Dopiero odejście w drugiej połowie XX wieku od humanistycznych wzorców, opartych na ideałach kształcenia przejętych z pism wybitnych filozofów starożytnych, greckich i rzymskich, spowodowało swoiste zagubienie w pedagogice i szerzej - kulturze współczesnej. Nie rozstrzygamy tu, czy był to obraz prawdziwy, czy zafałszowany. Trafnie ujęła go Zofia Mitosek, pisząc: „Mit antyczności, która jawiła się humanistom jako jedność sztuki i życia, jako spontaniczna, nierefleksyjna harmonia, określił na trwałe europejskie miary piękna"3. . Nie tylko zresztą piękna. W okresie greckiego antyku zostały również wypracowane inne kategorie estetyczne, dookreślając samą dziedzinę, dając przy tym wyraz szerokim i głębokim zainteresowaniom ówczesnych myślicieli. Jednym z najważniejszych jest bez wątpienia Arystoteles, który w swoich dwóch zwięzłych traktatach na temat poetyki i retoryki wniósł trwały wkład w rozwój badań nad literaturą i sztuką w ogóle.

Arystoteles, jak podkreślają badacze, skodyfikował europejską poetykę. Fakt ten wynikał z typowego dla Stagiryty podejścia metodologicznego, które zawierało kilka kroków. Filozof rozważał twórczość poetycką jako taką, ponadto jej rodzaje, także budowę utworu i wreszcie spełnianą przez niego funkcję. Innymi słowy, zasadniczym przedmiotem

${ }^{2}$ Zob. obszerne omówienie tych ujęć: H. Podbielski Wstęp [w:] Arystoteles Poetyka H. Podbielski (tł.) Warszawa 1988.

${ }^{3}$ Z. Mitosek Teorie badań literackich Warszawa 1998 s. 25. 
swoich rozważań Arystoteles uczynił zagadnienia „twórczości poetyckiej jako takiej i jej [rodzaje], jakie jest działanie każdego z nich i jak należy układać fabułę, jeżeli utwór ma wypaść artystycznie, a dalej o tym, z ilu i z jakich czynników składa się utwór"4. Szczególnie interesujące jest owo działanie, a więc funkcja utworu dramatycznego, która została wyrażona pojęciem katharsis.

Genologiczne cechy tragedii, a więc jej świat przedstawiony, miejsce zajmowane w nim przez bohatera, charakter (stylistyka) jego wypowiedzi, wywołują w odbiorcy stan wzruszenia tym silniejszy, im precyzyjniej zostają wyrażone w utworze jego składowe elementy oraz relacje między nimi. Rekonstruując system pojęć składowych i zależności między nimi, ważnych dla teorii tragedii Arystotelesa, zacząć wypada od pojęcia będącego podstawą dla zaistnienia naśladowania. Jest to fabuła, uporządkowany układ zdarzeń - mythos (,celem tragedii jest bieg zdarzeń, czyli fabuła”, „tragedia jest bowiem naśladowaniem nie ludzi, lecz działania (akcji) i życia”, 1450 a 20, 1450 a 15), następnie odtworzenie przebiegu wydarzenia - mimesis (,naśladowcze przedstawienie akcji poważnej, skończonej i posiadającej (odpowiednią) wielkość”, 1449 b 20) oraz określona stylistyka mowy (,wyrażone w języku ozdobnym, odmiennym w różnych częściach dzieła"), bezpośrednie zaangażowanie bohaterów w akcję (,przedstawienie w formie dramatycznej, a nie narracyjnej”), arogancja i zarazem buta - hybris (,,z rozmysłem wyzywa Przeznaczenie”), nieświadomy błąd bohatera - hamartia (który „nie popada w nieszczęście przez swą podłość i nikczemność, lecz przez jakieś zbłądzenie”, 1453 a 5), rozpoznanie jako przejście od niewiedzy do wiedzy - anagnorisis (,zwrot od nieświadomości ku poznaniu, ku przyjaźni lub wrogości”, 1452 a 30), i wreszcie odwrócenie losu, zmiana sytuacji bohatera peripeteia („odwrócenie biegu zdarzeń”, 1452 a 35). Zdaniem Arystotelesa, „najpiękniejsze jest takie rozpoznanie, które łączy się z perypetią (...), tego bowiem rodzaju rozpoznanie połączone z perypetią wzbudzi litość bądź trwogę" (1452 a 30-35), co jest zgodne z definicją tragedii. Na koniec, choć nie idzie za tym żadnego rodzaju wartościowanie, pozostaje do głębszego rozpatrzenia pojęcie katharsis.

Arystoteles użył jedynie kilkakrotnie terminu katharsis, z czego tylko raz $\mathrm{w}$ sensie definicyjnym. Zapewne dlatego pojęcie to stało się tak prowokujące i otwarte interpretacyjnie. Jak napisał Gerald F. Else, jeden

${ }^{4}$ Arystoteles Poetyka [w:] Trzy poetyki klasyczne, Arystoteles - Horacy - Pseudo-Longinos T. Sinko (tł.) Wrocław 1951 s. 3. Odpowiedni fragment w późniejszym thumaczeniu H. Podbielskiego brzmi następująco: ,sztuka poetycka jako taka, jej gatunki oraz właściwości każdego z nich, sposób, w jaki należy układać fabułę, jeśli utwór poetycki ma być piękny, jego składni ilościowe i jakościowe". Arystoteles Poetyka... wyd. cyt. 1447 a 5. Dalej odniesienia do Poetyki w tekście. 
z wybitnych współczesnych badaczy poetyki Arystotelesa, „wyrośliśmy w niejasnym poczuciu, że poważna literatura musi dostarczać 'katharsis', jeśli ma być poważana. 'Katharsis' stało się, z powodów nie do końca jasnych, jedną z najważniejszych 'wielkich' idei na polu estetyki i krytyki, Mount Everestem lub Kilimandżaro, majaczącym (loom) na wszystkich literackich horyzontach"5. Pojęcie to pojawiło się u Arystotelesa w pismach biologicznych i w Problemach. Nie są to wszakże użycia istotne. Najważniejsze jego znaczenia wiążą się z definicją tragedii podanej w Poetyce i rozwiniętej w Polityce, co merytorycznie może wydać się kolejnością poprawną, choć historycznie jest paradoksem. Chronologia powstania obu dzieł jest bowiem odwrotna, Polityka została napisana przed Poetyka. W niej znajdujemy dobrze znaną definicję tragedii, gdzie podmiotem zdania jest pojęcie mimesis, a jednym z elementów definicyjnych - pojęcie katharsis: „di' eleou kai fobou perainousa tēn tōn toioutōn pathēmatōn katharsin" (1449 b 27-28).

Definicja ta wzbudziła wiele kontrowersji, ale co szczególnie ważne, uprawomocniła wiele możliwości interpretacyjnych, które wynikały z różnych przesłanek: wieloznaczności użytych pojęć, wynikających stąd różnych, nawet rozbieżnych sensów sformułowanych zdań, ograniczonego wreszcie materiału, mogącego służyć do dalszej pogłębionej analizy. Trudności interpretacyjne przedstawionego powyżej fragmentu definicji, wynikające $\mathrm{z}$ rozumienia lub nierozumienia poszczególnych jej elementów, wyraźnie pokazuje jego analiza filologiczna ${ }^{6}$. Czy przedrostek dia posiada sens instrumentalny, a oczyszczenie następuje wówczas „dzięki” uczuciom litości i trwogi, a więc ,za ich pomocą”, czy też przedrostek ten wyraża kierunek, a wówczas oczyszczenie zachodzi „poprzez” te uczucia? Czy perainein oznacza w tym przypadku tyle, co „spełniać, realizować, urzeczywistniać się”, czy raczej znaczy „osiągać coś”, „doprowadzać do końca"? Czy toioutōn jest zaimkiem wskazującym, czy też wiążąc się z pathēmatōn, oznacza wówczas „tego rodzaju (uczucia)”? Czy wyrażenie tōn toioutōn pathēmatōn katharsin jest konstrukcją wyrażającą genetivus zwykły i dającą w efekcie sens „oczyszczenie tych uczyć”, czy może należy wyrażenie to uznać za genetivus separativus, co zmieniłoby jego sens na „oczyszczenie od uczuć”? Czy pathēma, w znaczeniu „uczucie”, „doznanie”, odnosi się do sfery psychicznej: „naśladowcze przedstawienie wzbudzajace litość i strach", czy też może ma związek ze sferą literacką: „naśladowcze przedstawienie o cechach litości i strachu"? I wreszcie najważniejsze pytanie dotyczy sensu katharsis, który

${ }^{5}$ G.F. Else Aristotle's Poetics: The Argument Harvard, Cambridge 1957 s. 439.

${ }^{6}$ Zob. E. Sarnowska-Temeriusz Zarys dziejów poetyki. Od starożytności do końca XVII w. Warszawa 1985 s. 177-179. 
rozpada się na dwa możliwe ujęcia. Czy sens ten jest zewnętrzny i wówczas dotyczy odbiorcy w kilku aspektach: religijnym, łącząc się z éxtasis, medycznym, odsyłając do purgatio, bądź raczej etycznym, przywołując purificatio, czy wreszcie estetycznym, łącząc się z transformatio? A może jednak sens ten jest wewnętrzny i wówczas ma charakter literacki, w którym katharsis ogranicza się do procesu przedstawionego w samym dziele? Wszystkie te pytania są o tyle istotne, że udzielenie na nie wiążącej odpowiedzi pozwoliłoby rozstrzygnąć, czy definicja Arystotelesa stosuje się jedynie do teorii tragedii, czy również do teorii jej odbioru.

W rezultacie tłumacze Poetyki oddają fragment definiujący tragedię w odmienny sposób. Przywołajmy przekłady obecne w języku polskim, których autorami są trzej znawcy antyku greckiego i filozofii Arystotelesa: (1) Tadeusz Sinko (1953 r.), (2) Władysław Tatarkiewicz (1960 r.) i (3) Henryk Podbielski (1983 r.). Przekłady, choć różnią się w całościowym wyrazie, w swych ostatnich członach wyrażają wspólne dla wszystkich tłumaczy przekonanie o zewnętrznym, psychologicznym sensie pojęcia:

(1) Jest tedy tragedia naśladowczym przedstawieniem czynności (akcji) poważnej, skończonej w sobie, o określonej wielkości, przedstawieniem wyrażonym w mowie ozdobnej, przy czym każdy rodzaj ozdób jest właściwy poszczególnym częściom, za pomocą osób działających, a nie przez opowiadanie, i dokonującym przez wzbudzenie litości i trwogi (właściwego sobie) oczyszczenia tego rodzaju afektów ${ }^{7}$.

(2) Tragedia jest naśladowczym przedstawieniem akcji poważnej, zamkniętej w sobie i posiadającej określoną wielkość, wypowiedzianym w mowie ozdobnej, zróżnicowanej w każdej swej części; przedstawieniem nie w formie opowiadania, lecz przez działanie, które przez to, że wzbudza litość i trwogę, dokonuje oczyszczenia takich uczuć ${ }^{8}$.

(3) Tragedia jest to naśladowcze przedstawienie akcji poważnej, skończonej i posiadającej (odpowiednią) wielkość, wyrażone w języku ozdobnym, odmiennym w różnych częściach dzieła, przedstawione w formie dramatycznej, a nie narracyjnej, które przez wzbudzenie litości i trwogi doprowadza do oczyszczenia [kótharsis] tych uczuć9.

${ }^{7}$ Arystoteles Poetyka [w:] Trzy poetyki klasyczne... wyd. cyt. s. 13.

${ }^{8}$ Tenże Poetyka W. Tatarkiewicz (tł.) [w:] W. Tatarkiewicz Estetyka starożytna t. 1 Warszawa 1960 s. 192 . W przekładzie o szesnaście lat późniejszym Tatarkiewicz różnicuje jedynie stylistykę, nie zmieniając w zasadzie istotnego sensu definicji: „Tragedia jest naśladowczym przedstawieniem akcji (...); wzbudza współczucie i strach i przez to oczyszcza te uczucia". Tenże Poetyka W. Tatarkiewicz (tł.) [w:] Arystoteles. David Hume. Max Scheler. O tragedii i tragiczności W. Tatarkiewicz (wybór, przedm., oprac.) Kraków 1976 s. 25.

${ }^{9}$ Tenże Poetyka H. Podbielski (tł.) Wrocław 1983, 1449 b 24-27. 
Cytowane przykłady mówią o wzbudzaniu określonych uczuć odpowiednim przebiegiem akcji. Sama czynność wzbudzania wskazuje kierunek i cel oddziaływania, co prowadzi do zasadniczej kwestii dotyczącej ulokowania katharsis. W podanych przypadkach oczyszczenie katartyczne jest lokowane na zewnątrz owej akcji, a więc po stronie odbiorcy bądź aktora, nie można go bowiem wykluczyć z tej sfery. Jest oczywiście możliwe przeciwne podejście, a więc wewnętrzne ulokowanie oczyszczenia. Tu stajemy wobec interesującego nas problemu.

Zasadnicza linia podziału dotyczy opcji wewnętrznej lub zewnętrznej ulokowania katharsis. Problem można wyrazić pytaniem, czy katharsis jest końcowym efektem w psychice i umysłach publiczności, czy też jak głosi Else - łańcuchem wydarzeń dziejących się w ramach samej struktury tragedii, co prowadzi do oczyszczenia tychże wydarzeń oraz ich bohaterów, a czego siłą napędową jest anagnorisis, rozpoznanie. Za pierwszym rozwiązaniem opowiadała się niemal cała historia odczytań Poetyki, różnicując się wewnętrznie. Drugie rozwiązanie przedstawił w XX w. wspomniany powyżej Gerald F. Else, wywołując burzę protestów i krytyki. To bowiem, co wydawało się nie podlegać dyskusji, a więc samo usytuowanie katharsis po stronie odbiorcy, zostało przesunięte do struktury samego dzieła tragicznego. Oba stanowiska różnicuje odmienne (nieformalne bądź formalne) odczytanie podejścia Arystotelesa do przedmiotu Poetyki.

2.

Katharsis wieloaspektowe

Wszystkie te interpretacje, wychodząc z różnych przesłanek, a mówiąc precyzyjniej: wychodząc poza filozofię sztuki, sięgają do takich dziedzin, jak: religioznawstwo, medycyna, psychologia (psychoanaliza), antropologia filozoficzna, pedagogika, zyskując charakter religijny, medyczny, terapeutyczny, etyczny i wreszcie estetyczny. Ten ostatni - istotny dla wykładni ujęcia Arystotelesowego - jest najbardziej interesujący.

$\mathrm{Z}$ pierwszym mamy do czynienia w Polityce, gdzie Stagiryta przy okazji przedstawiania charakterystyki muzyki - pisze: „Jestem tego zdania, że muzykę należy uprawiać nie dla jednego, ale dla wielu pożytecznych celów, bo i dla wykształcenia, i dla duchowego oczyszczenia, czyli tzw. katharsis - co zaś nazywam katharsis, teraz ogólnie tylko zaznaczam, bo później, mianowicie w Poetyce, dokładniej to omówię po trzecie zaś i dla wypełnienia czasu spoczynku, dla odprężenia i wy- 
tchnienia po pracy"10. Ta zapowiedź zostaje w Polityce dodatkowo wsparta kilkoma uogólnieniami obserwacji empirycznych, które niewiele wnoszą do wyjaśnienia terminu ${ }^{11}$. Drugie z kolei jego użycie znajdujemy w znanym już fragmencie Poetyki, gdzie Stagiryta, określając istotę tragedii, pisze w konkluzji, że tragedia poprzez wywołanie pewnych emocji

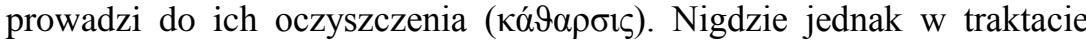
termin ten nie zostaje ponownie przywołany i wyjaśniony.

Sytuacja ta, trudna dla samego rozumienia pojęcia, ułatwiła późniejszym komentatorom formułowanie propozycji interpretacyjnych o różnym stopniu wierności nie tyle wobec myśli teoretycznej (estetycznej) samego Arystotelesa, bo ta bezpowrotnie przepadła, co wobec języka i kultury greckiej. Propozycje te zaczęły powstawać od momentu pojawienia się manuskryptu w Europie, a więc gdy uciekinierzy z upadającego Bizancjum przywieźli go do Wenecji w połowie XV w. Choć komentarzy jest wiele, uderza brak zgody we wszystkich niemal kwestiach historycznych i teoretycznych. Trudno się dziwić, jeśli do dzisiaj wątpliwości budzi najważniejsza bodaj sprawa, mianowicie to, jak wielka część traktatu jest oryginalnym dziełem Arystotelesa, a jaka wyszła spod rąk jego uczniów. Wobec nierozstrzygalności tych pytań próbowano ustalić, kto w starożytności znał Poetykę i bezpośrednio z niej cytował, by w ten pośredni sposób zbliżyć się do postaci oryginalnego dzieła. Ale i ten problem nie ma szans na wyjaśnienie z powodu niewielkiej ilości zachowanych dzieł pisarzy starożytnych ${ }^{12}$. Stąd też brak jednoznacznej wiedzy, jak Arystoteles rozumiał podstawowe dla swojej teorii terminy, jak mimesis, éthos, éleos, phóbos, hamartia, peitho i wreszcie katharsis. Dlatego zaskakująca opinia Podbielskiego wydaje się słuszna: „Wziąwszy pod uwage rozliczne i owocne koncepcje artystyczne i naukowe, jakie wyrosły na tle nieporozumienia związanego $\mathrm{z}$ wieloznacznością i «nieostrym» użyciem greckiego terminu katharsis, wydaje się, że ostateczne wyjaśnienie znaczenia tego pojęcia w Poetyce byłoby nawet niekorzystne dla jego inspirującej roli kulturotwórczej"13.

${ }^{10}$ Arystoteles Polityka L. Piotrowicz (tł.) Warszawa 1964, 1341 b 4.

${ }^{11}$ Pisze tu Arystoteles: „Takie samo wrażenie muszą odczuwać ci, którzy są skłonni do uczucia litości i strachu i w ogóle ludzie wrażliwi, inni zaś, o ile kogoś któreś z tych uczuć poruszy; wszyscy jednak odczuwają w takim razie pewne oczyszczenie i ulgę połączoną z rozkoszą. Podobnie i śpiewy o takim oczyszczającym duszę charakterze sprawiają ludziom nieszkodliwą uciechę". Tamże 1342 a 6.

${ }^{12}$ Por. H. Podbielski Wstęp [w:] Arystoteles Poetyka H. Podbielski (tł.) Warszawa 1983 BN II 209. Także: M. Sugiera Mythos, katharsis i mimesis: nowe lektury „Poetyki” Arystotelesa [w:] Po strukturalizmie. Wczesne badania teoretycznoliterackie R. Nycz (red.) Wrocław 1992 s. 137-152. Obie pozycje dają gruntowny przegląd interpretacji Poetyki.

${ }^{13}$ H. Podbielski Wstęp [w:] wyd. cyt. s. LXI. 
Taka sytuacja pozwala na znaczne dowolności interpretacyjne, które można uogólnić i podciągnąć pod określone typy. Giovanni Reale zaproponował przejrzysty typologicznie podział, wyróżniając trzy sensy związane z kategorią katharsis: magiczno-religijny, filozoficzno-racjonalny i poetycko-estetyczny, z ostatnim łącząc Arystotelesa ${ }^{14}$. Autorem obszernego omówienia dotychczasowych ujęć pojęcia katharsis jest Podbielski, proponujący również własną interpretację. W jego systematyzacji znajdujemy omówienie ujęcia medycznego, religijnego, etycznego, estetycznego i - propozycja własna - estetyczno-intelektualnego. Podbielski koncentruje swoją uwagę na relacji między procesem mimetycznym, czyli przedstawieniem świata uporządkowanego przez artystę, a procesem katartycznym, czyli przeżyciem intelektualno-uczuciowym tegoż świata przez odbiorcę. Dla tych uwag istotne jest to, że drugi człon relacji dotyczy jednostkowego człowieka, jego przeżyć i reakcji odbiorczych ${ }^{15}$.

Odsyłając czytelnika zainteresowanego filozoficznymi interpretacjami kluczowych pojęć Poetyki do bogatej literatury przedmiotu, pragnę tu zastanowić się nad wymiarem odniesienia pojęcia katharsis, co ma określone znaczenie dla dalszych uwag. Chodzi tu innymi słowy o problem, który wyraża następujące pytanie: czy katartyczna funkcja sztuki ma u Arystotelesa wymiar jednostkowy, czy zbiorowy? A jeśli ten drugi, to jaki sens ma owa zbiorowość? Ten problem nie był zasadniczy dla analizy istoty tragedii przedstawionej w Poetyce, stąd uwagi na ten temat pojawiają się raczej sporadycznie w komentarzach i omówieniach. Dlatego też odkrywcze znaczenie zyskuje propozycja Bruniusa, rozszerzająca zakres oddziaływania kategorii katharsis.

Brunius stwierdza, że Arystoteles przejął poglądy Platona dotyczące uczuć i doświadczenia dzieła sztuki, które łączyły w jedną całość, w jeden łańcuch, separowane zwyczajowo elementy, jak bóg (Muzy), poeta, rapsod (aktor) i odbiorca. Źródeł potwierdzających to stanowisko nie znaj-

${ }^{14}$ G. Reale Historia filozofii starożytnej t. 5 E.I. Zieliński (tł.) Lublin 2002 s. 106. Por. również: B. Dziemidok.

${ }^{15}$ Podbielski wyznacza tu następujące zależności: „dzięki temu, że mimesis stanowi świat uporządkowany, oparty na wewnętrznej logice prawdopodobieństwa i konieczności, umysł odbiorcy dokonuje oceny: nieszczęście dotknęło człowieka a) niewinnego, b) podobnego do mnie. $Z$ kolei «niewinność» na zasadzie «sympatii» wywołuje w sferze uczuciowej odbiorcy litość, «podobieństwo» zaś wywołuje trwogę. W tym samym momencie rozpoczyna się następny proces; umysł poznaje, że to nieszczęście dzieje się w świecie fikcji. Dystans fikcji i logika wewnętrzna przedstawionego świata dokonuje «sublimacji» (oczyszczenia) uczuć, sprowadzając je do właściwej «miary», dzięki czemu, zgodnie z Arystotelesowską definicją cnoty, stają się przeżyciem pozytywnym (cnotą) i sprawiają przyjemność”. H. Podbielski Wstęp wyd. cyt. s. LXXXVIII. 
dujemy wiele w dziełach Stagiryty, nie mają też one bezpośredniego charakteru. Pierwszym źródłem - w układzie ważności - jest zakończenie Polityki, gdzie Stagiryta, dyskutując o wartości muzyki, odnosi się do Sokratesa: „niektórzy ze znawców muzyki słusznie czynią Sokratesowi i ten zarzut, że odrzucał spokojne tonacje przy nauce, ponieważ uważał je za oszałamiające"16. Jest to zasadniczy dowód, że kontynuuje on wcześniejszą, Platońską teorię natchnienia. Drugim źródłem jest Retory$k a$, gdzie Arystoteles pisze o źródle natchnienia. Trzecim i właściwym jest Poetyka, gdzie mówi on o identycznym stanie umysłu na drodze od poety do odbiorcy. Ta identyczność - możemy dodać - nie wynika z obecności boskiej inspiracji, lecz raczej z identyczności natury ludzkiej, a więc podobieństwa (homoiosis) reakcji w określonej sytuacji. Pisze tu, że „W miarę swych możliwości powinien również poeta dopomóc sobie gestami. Bo najbardziej przemawiają do przekonania ci, którzy wczuwają się w naturę postaci. Najbardziej oburza - kto jest oburzony, i okazuje gniew - kto jest zagniewany" (1455a 25-30). Nie ma wątpliwości, że mamy tu łańcuch zależności artystycznej: poeta: postać sceniczna - aktor: ten, który przemawia (do przekonania) - odbiorca: ten, do którego przemowa jest skierowana (by zareagował owymi przekonaniami). Warto zauważyć, że Stagiryta formułuje tu postulat realistycznego traktowania gry aktorskiej; artysta odtwarza (naśladuje) emocjonalny potencjał postaci stworzonej przez poetę, widz przeżywa uczuciowo oglądany efekt naśladownictwa. Ogniwa łańcucha, u Platona inicjowanego boskim natchnieniem, tworzą jednokierunkowy związek tragiczny, o zstępującej zależności.

Arystoteles usuwa ze swojego łańcucha element pierwszy, mitologiczny, czyli udział Muz w akcie twórczym. Pozostaje więc relacja między poetą i odbiorcą, relacja również wieloelementowa. Usunięcie pierwszego ogniwa zmienia wszelako optykę, bowiem następuje zamiana podejścia mitologicznego na psychologiczne. To oznacza obrót związanej $\mathrm{z}$ tragedią problematyki emocji wokół własnej osi i nadanie im charakteru teoretycznego, naukowego. Ten nowy aspekt naukowości nie znajduje rozwinięcia w starożytności, sam Arystoteles rozpoczyna go tylko; jego czas nadejdzie dużo później. Nie można tu jednak pominąć ważnych pytań dotyczących relacji ucznia do mistrza. Czy Stagiryta faktycznie powiela Platona? Czy za powielenie można uznać wykorzystanie naturalnej przecież relacji między elementami sytuacji tragicznej?

To, co było naganą u Platona, zyskuje walor pochwały u Arystotelesa. Dla pierwszego siła emocjonalnego oddziaływania sztuki blokowała zdolność myślenia człowieka, stąd poeta i dzieło sztuki nie zasługiwali

${ }^{16}$ Arystoteles Polityka L. Piotrowicz (tł.) Warszawa 1964, 1342 b 11. 
na przychylność filozofa. Podstawą oceny artysty przez Platona jest jego redukcjonistyczne postrzeganie istoty człowieka. Dla drugiego owa siła otwierała człowieka na swoje wnętrze i uwalniała tym samym przeżycie i poznanie jego treści. Ten aspekt nie został w pełni dostrzeżony w podejściu Bruniusa oraz innych komentatorów teorii tragedii Arystotelesa, bowiem podkreśla się w nim wyłącznie psychologizm. Bogatsza poznawczo jest propozycja antropologicznego ujęcia twierdzeń Stagiryty przedstawiona przez Mieczysława A. Krąpca. Arystoteles nie podważa w tym ujęciu rozumności człowieka jako jego kryterialnej własności, bowiem rozumność ta zapewnia mu spełnienie jego istotowych celów, pozwalając na poznanie prawdy. Różnicuje go wszelako wobec Platona zakres procesu poznawczego, do którego należą również wyższe uczucia człowieka. Są to wskazane w definicji tragedii uczucia litości i trwogi, które „pojawiają się w obecności zła zagrażającego realnemu dobru"17. To zagrożenie ,powoduje - jak zauważa Krąpiec - psychiczne pobudzenie uczuciowe, mające na celu przezwyciężenie zła lub ocalenie dobra, a przez to wprowadzenie wewnętrznego, psychicznego ładu, który umożliwi kontemplację prawdy" ${ }^{\prime 1}$. Nie ma wątpliwości, że to podważa akceptowaną powszechnie tezę o estetycznej bezinteresowności, gdyż odbiorca nie pozostaje w istocie obojętny na prawdę i dobro, które „tworzą głębię dzieła sztuki (...). Dlatego angażujemy się «całym sobą» w świat przedstawiony i dlatego musimy «ochłonąć» i zdystansować się do jego warstwy fenomenalnej, tworzonej przez postaci i ich losy, aby zmierzyć się z rzeczywistym dramatem: dramatem prawdy i dobra. $\mathrm{O}$ istnieniu tego dramatu świadczą dzieła kanoniczne: arcydzieła"19.

Interesującej interpretacji, niejako podsumowującej i zamykającej namysł nad koncepcją Arystotelesa, dokonał angielski badacz R.G.A. Buxton. Pokazał on, że wielozakresowość światopoglądowa obecna w myśleniu Arystotelesa kłoci się ze współczesnym, wąsko specjalistycznym postrzeganiem świata. Buxton $\mathrm{w}$ swojej analizie związanego $\mathrm{z}$ kategorią katharsis greckiego pojęcia peitho odsłonił jego szeroki zakres znaczeniowy, obejmujący retorykę, psychologię, etykę, politykę i filozofię. $\mathrm{W}$ efekcie tak szerokiego ujęcia problemu można sformułować zasadnicze pytania, dotyczące oddalonych od siebie okresów w kulturze europejskiej. Czy współczesny człowiek, z jego mocno ugruntowanym nawykiem analitycznego podejścia do świata, może zrozumieć całościowe jego

${ }^{17}$ H. Kiereś Człowiek i sztuka. Antropologiczne watki problemu sztuki Lublin 2006 s. 110.

${ }^{18}$ M.A. Krąpiec Od mimesis do katharsis [w:] tenże $U$ podstaw rozumienia kultury Lublin 1991 s. 214.

${ }^{19}$ H. Kiereś, dz. cyt. s. 111. 
postrzeganie przez starożytnego Greka? Czy logotyczną jedność świata człowieka starożytności można zastąpić społeczną jednością świata człowieka współczesnego? Innymi słowy, czy metafizyczny logos antyku można zastąpić pragmatyczno-socjologicznym rozumem? Można mieć poważne wątpliwości, gdyż zbyt głęboka różnica „dzieli światopogląd Arystotelesa od naszego widzenia świata, zdominowanego przez myśl chrześcijańską, przez wysoki stopień specjalizacji, który każe dostrzegać różnice tam, gdzie Grecy widzieli tożsamość" ${ }^{20}$.

\section{Aristotle's Emotionalism and the Meaning of the Concept of Catharsis}

The author suggests that pity, fear, and catharsis are experienced not only by the audience but by the playwright and actors as well. This, of course, inevitably involves him in the old problem of whether the actor him-self must feel the emotions that he is trying to portray. Furthermore, Brunius suggests that the three elements are already in evidence in the original story behind the tragedy.

Leszek Sosnowski-e-mail: 1s@iphils.uj.edu.pl

${ }^{20}$ M. Sugiera Mythos, katharsis i mimesis... wyd. cyt. s. 150. 